\title{
Changes of Poor Family Behavior Through Family Development Session
}

\author{
$1^{\text {st }}$ Suradi* \\ Pusat Penelitian dan Pengembangan \\ Kesejahteraan Sosial \\ Kementerian Sosial RI \\ Jakarta, Indonesia \\ mas.soeradi@yahoo.co.id \\ $4^{\text {th }}$ Sugiyanto \\ Pusat Penelitian dan Pengembangan \\ Kesejahteraan Sosial \\ Kementerian Sosial RI \\ Jakarta, Indonesia \\ sugiyantospdmsi@gmail.com
}

\author{
$2^{\text {nd }}$ Nyi R Irmayani \\ Pusat Penelitian dan Pengembangan \\ Kesejahteraan Sosial \\ Kementerian Sosial RI \\ Jakarta, Indonesia \\ irmayani.kemsos@gmail.com \\ $5^{\text {th }}$ Badrun Susantyo \\ Pusat Penelitian dan Pengembangan \\ Kesejahteraan Sosial \\ Kementerian Sosial RI \\ Jakarta, Indonesia \\ besusantyo@gmail.com \\ $7^{\text {th }}$ Togiaratua Nainggolan \\ Pusat Penelitian dan Pengembangan \\ Kesejahteraan Sosial \\ Kementerian Sosial RI \\ Jakarta, Indonesia \\ togiaratua@gmail.com
}

\author{
$3^{\text {rd }}$ Habibullah \\ Pusat Penelitian dan Pengembangan \\ Kesejahteraan Sosial \\ Kementerian Sosial RI \\ Jakarta, Indonesia \\ habibullah@kemsos.go.id \\ $6^{\text {th }}$ Benecdiktus Mujiyadi \\ Pusat Penelitian dan Pengembangan \\ Kesejahteraan Sosial \\ Kementerian Sosial RI \\ Jakarta, Indonesia \\ bmujiyadi@yahoo.co.id
}

\begin{abstract}
Poverty reduction has become a priority for government of the Republic of Indonesia in the last decade. One among poverty reduction programs based on family called Program Keluarga Harapan (PKH). PKH is a conditional cash transfer (CCT) program for poor families. PKH has addressed to cut off poverty chain through the accessibility of education, health, and social welfare services. PKH beneficiaries, besides getting social assistance in the form of cash transfer, also received capacity building in the form of Family Development Sessions (FDS). FDS has formed as behavioral change intervention that carried out by PKH Facilitator. This study has aimed to describe and analyze the implementation of FDS and changes in poor family behavior. Qualitative approach has been used for this research with an open-ended interview as a collective data technique. The FDS meeting was held at beneficiaries' household, and public facilities. The findings of this study indicate that the implementation of FDS is highly dependent on the competency of PKH Facilitator, frequency has done once a month, each for two hours. Teaching aids in the form of modules and flipcharts. The FDS material consists of education and parenting, economics, health, and child protection. Changes in Poor Family Behavior include being able to regulate household financial planning, healthier lifestyles, childcare and care for the elderly and disability. This study recommends the need for material adaptation according to regional conditions. The economic module needs to be added to the session on social entrepreneurship, especially for PKH beneficiaries who will graduate.
\end{abstract}

Keywords-conditional cash transfer, poverty, family development session, social change

\section{INTRODUCTION}

Conditional Cash Transfer (CCT), is a model of social intervention for poor families through the distribution of social assistance. The CCT model has been implemented in various countries driven by the World Bank. The program, known as an anti-poverty tool or program [1] is considered to contribute to the ease of family access to health services, health status and nutritional intake of children [2] [3] [4] [5] [6] and access to education and school participation in school-age children in poor families [7] [8][9] [10].

Even though CCT as an anti-poverty program has a positive impact in enlarging access for poor families to health and education facilities, a number of deficiencies have been found. The evaluation results in Mexico, that CCT is considered effective for short-term programs, while for long-term programs have considered no longer effective, and other models need to be found [11]. The lesson learned from Bolivia, the ineffectiveness of CCT is not in the design of the program, but in the implementation of programs in the field, such as inclution or exclution error, stigmatization of beneficiaries and creating social jealousy [12].

The CCT model in Indonesia, called the Program Keluarga Harapan (PKH)[13], is Indonesia's effort to build a social protection system for poor families. This program began in 2007 as a social protection scheme for dealing with poverty. Cash transfers from CCT have been adapted based on strong political motivations from policy makers for popular support in the context of democratization [14] .This cash transfer policy will provide an important impetus for the development of a social protection system in post-crisis and reform of model of Indonesia[15][16].

$\mathrm{PKH}$ requires that each beneficiary must comply with applicable regulations and participate actively in education and health. PKH beneficiaries who do not comply with the provisions, then get sanctions as stipulated in the guidelines [17]. So far, beneficiaries have complied with applicable regulations, so that nothing has been excluded from PKH. However, for more than six years as a PKH beneficiary, there has not been a significant change in behavior and 
socioeconomic conditions at beneficiaries. Even beneficiaries which have not fulfilled the requirements, are not ready to be issued (graduation) from PKH[18]). KPM $\mathrm{PKH}$ unpreparedness enters the graduation phase, which is the underlying condition required for the Family Development Session (P2K2) for beneficiaries. Therefore, $\mathrm{P} 2 \mathrm{~K} 2$ is an activity that must be followed by every beneficiary. This activity is in direct contact with the change in the mindset and behavior of beneficiaries, where changes in the mindset and behavior are critical to the success of PKH.

Five modules were prepared in this $\mathrm{P} 2 \mathrm{~K} 2$ activity, and each module consisted of 3-4 sessions. These five modules are: childcare and education, health and nutrition, financial planning and business management, child protection and social welfare. The modules contain material compiled based on the results of the assessment of the problems and needs of the families of the poor. Issues regarding education, health, economy, and child protection, are various issues that characterize family life.

$\mathrm{P} 2 \mathrm{~K} 2$ is carried out by PKH facilitators who have been trained by Education and Training Institutions of the Ministry of Social Republic of Indonesia in six regions, namely Padang, Bandung, Yogyakarta, Banjarmasin, Makssar and Papua. The training was held for five days, and in a very short time the facilitator was expected to master the five modules that had been prepared. The preparation of assistants through the $\mathrm{P} 2 \mathrm{~K} 2$ training is based on their role as agents of change for beneficiaries. This role as an agent of change requires that the facilitator have the skills and strength to stimulate, facilitate and coordinate efforts for change [19]. As an agent of change, the companion will be the link between the source of the idea of change with the target community [20].

Through FDS activities, beneficiaries obtained knowledge, skills, attitudes, and behaviors, so they were expected to be able to break-off the poverty chain. The new knowledge, skills, attitudes and behaviors are related to childcare and education; health and nutrition; financial management and business planning; child protection and social welfare. Changes in KPM behavior are outcomes of FDS activities as well as outcomes in PKH. Therefore, it is expected that with the knowledge and skills gained, beneficiaries' potencies and resources can be explored and developed, so that they can independently left PKH or enter the graduation phase.

Several research has been done on $\mathrm{PKH}$, and more has been seen from the process and institutional aspects [21] [22] [23]. Meanwhile, research that discusses the effect of FDS on beneficiaries' behavior is still very limited. This is what underlies the need for this research, which is expected to contribute to the strengthening and/or development of the FDS program going forward.

\section{METHOD}

The research was conducted by focusing on the effect of FDS activities on changes in beneficiary's behavior. The study was conducted in 6 (six) locations, namely West Sumatra, West Java, Jogjakarta, South Kalimantan, South
Sulawesi and Papau. Informants in this study, PKH facilitators were 12 people and beneficiaries were 60 people. Data were collected using study desk methods, in-depth interviews, focus group discussions and field observations. While Qualitative data analysis on aspects of beneficiaries' behavior change was based on modules that have been implemented.

\section{RESEARCH RESUltS AND Discussion}

\section{A. Child care and education}

Before joining FDS, beneficiaries did not have any knowledge regarding how to behave properly for their children. It means to educate children to be good children, but in the wrong ways. Beneficiaries do physical violence (hitting, slapping, pinching), and psychological violence (yelling, scolding, calling poorly) and do not reward children when children perform in school or do good work. Violence against children is sometimes done not solely the child's fault, but as an outlet when parents fight. Togetherness with children is rarely done because of busy parents meet the family needs.

After joining FDS, PKH beneficiaries began to leave their poor behavior to their children. $\mathrm{PKH}$ beneficiaries give good directions, gives the child time to reflect on his mistakes and persuade the child, and let the child solve his problems himself. Being friends to share listen and pay attention to children when talking. Accompany children to play and watch TV, help children learn at home, and direct children to ask people who are more understanding about schoolwork.

Beneficiaries tries to hold back emotions, be patient in handling children, keep words, and be assertive in giving positive direction to children. Give praise and appreciate the child for the child's success in doing the task, being a good friend to the child and trying to help the child learn at home. Establish communication with the teacher or homeroom teacher to obtain information about the condition of children in school.

\section{B. Child protection}

Before joining FDS, KPM's knowledge of child protection was still limited. Beneficiaries commonly do not yet realize the rights that parents must give to their children. Beneficiaries do not realize yet that attention, affection, education, and health, are children's rights that must be given by their parents. Even so, parents always pray for their children to be good children and succeed in their lives later.

After joining FDS, beneficiaries have better understood the rights of children, and the obligation for parents to fulfill them. Beneficiaries also understand mistreatment of children and realize that what has been done to their children is inappropriate behavior. Beneficiaries understand that hitting, angry, and insulting children is an act of violence, although intended to provide education for children to behave properly. 


\section{Child protection}

Before getting FDS, beneficiaries sought treatment when sick by accessing the nearest and trusted health institutions such as puskesmas and hospitals. They are asked to consume all food that are available and can be purchased such as, vegetables, tempeh, tofu, and salted fish.

After joining FDS, beneficiaries tried to routinely check health even before being sick. Also, to Consume foods that are nutritious and can be purchased such as vegetables, tempeh, tofu, salted fish, and other protein foods.

\section{Financial management and business planning}

Beneficiaries of PKH that called KPM is generally from low income families. Before getting assistance through FDS, beneficiaries had never planned family finances. Beneficiaries in general have never recorded income and expenditure of family finances. Beneficiaries have not been saving or dealing with banking so far. Some beneficiaries are forced to borrow money from moneylenders when facing financial problems, and face problems when repaying the debt. Beneficiaries have not been able to do entrepreneurship well. The behavior shown is that beneficiaries have business skills but cannot be improved because of limited capital.

After joining FDS, beneficiaries were careful in borrowing money. The behavior is shown, namely by borrowing money from parties that do no harm such as family. Beneficiaries plan family finances by recording needs and expenses and starts saving even in small amounts. Beneficiaries chose not to owe and understand risks when borrowing money. Beneficiaries know how to do entrepreneurship, although at present it cannot be realized due to limited access to capital. Before joining FDS, beneficiaries who lived with the elderly or with disabilities, had given care. What has been done so far according to beneficiaries has been good, namely by providing food, clothing, and shelter in accordance with their socioeconomic conditions. However, it is still rare to do joint activities, because the beneficiaries are preoccupied with economic affairs of the family and taking care of their children. Likewise, togetherness with disability is still very lacking.

After joining FDS, beneficiaries have new knowledge on how to behave towards the elderly and or with disabilities that live with them. Beneficiaries seek to increase time together with the elderly and or with disabilities and involve them when making decisions that affect them.

Changes in poor family behavior through FDS are the outcome of FDS activities and at the same time become a condition that leads beneficiaries to enter the graduation phase of establishing. Where this independent graduation becomes an outcome and indicator of PKH success [15] [17]. Changes in beneficiaries' behavior are carried out by PKH facilitators who have attended FDS training for five days. Through FDS training, each companion is required to master five modules, namely childcare and education, health and nutrition, financial planning and business development, child protection and social welfare.
The results showed that FDS activities on $\mathrm{PKH}$ influence the behavior of beneficiaries. FDS modules delivered by the facilitator to beneficiaries, add new knowledge, awareness, motivation, and then take actions that have not been done so far, and or strengthen actions that have been done so far for the better.

With the knowledge and skills mastered, PKH facilitators can change Poor family behavior. Referring to the above research results, in addition to mastering the material in the FDS modules, the facilitator can understand the factors of individual behavior change. Then there is a process of transfer of new knowledge, and generate awareness related to childcare and education, health and nutrition, financial planning and business development, child protection and social welfare.

Discussing behavior change, there are various factors that influence, namely personal, social, and environmental factors. Personal or individual: beliefs, knowledge, attitudes, skills, genetics; social: interaction with others including friends, family and community; and environment: the area of residence of individuals, for example schools, workplaces, shops and local facilities, and broader factors including the economy (such as price) and technology. This view is supported by Robertson, that a person experiences changes in behavior influenced by various factors, namely strong determination, knowledge and skills, social motivation, social ability, structural motivation, and structural ability [24].

Various arguments in favor of a strong determination, attitude, knowledge, skills, confidence and motivation; an internal factor that has a big influence on the occurrence of changes in a person's behavior [25] [25] [26] [27]. These arguments assert that internal factors in a person are the main factors targeted for intervention. The implication of this assertion is that the implementation of FDS requires PKH facilitators to have the skills to build strong social relations with beneficiaries.

However, behavior change due to internal factors requires the support and reinforcement of social and environmental factors. That social and environmental situation, strengthen someone in making decisions to make changes in behavior [28] [29]. This has implications, that the implementation of FDS requires PKH facilitators to have deep understanding of the socio-cultural and environmental dimensions in which beneficiaries' lives.

\section{CONCLUSIONS}

Changes in poor family behavior that occur in certain fields are case based, because not all beneficiaries receive material from 5 (five) FDS modules prepared. In 6 (six) research locations, the FDS modules applied were less than 5 (five) modules prepared. For example, in Makassar, there are only 2 (two) modules, namely the childcare and education modules, and the financial planning and business management modules, of the 5 (five) modules prepared.

Of the 60 respondents, all claimed to have benefited from participating in FDS. They have better knowledge and understanding from the companion regarding childcare and education, child protection, health and nutrition, financial 
management and business planning, and social welfare. After having new knowledge and understanding, behavior changes occur based on the results of the analysis on aspects of knowledge, understanding, application, analysis, synthesis and evaluation, after beneficiaries have got a FDS companion. But the change in poor family behavior is not permanent because it has only been implementing the FDS module for three months in daily family life.

This research recommendation:

1. FDS facilitating will be sustainable and it is likely to occur repetitions, and therefore the facilitator is required to increase mastery of the contents of each module through discussions with fellow mentors, with experts and or with facilitators (widyaiswara) at $\mathrm{BP} 2 \mathrm{KS}$ in 6 regions.

2. Although facilitator currently only requires a portion of the modules out of 5 (five) modules prepared in FDS, the facilitator is responsible for delivering the other modules as a tool to change poor family behavior.

3. Submission of FDS modules is not rigid. For example, once a month in a group meeting at the RW office. However, the FDS module can be delivered flexibly without being limited by time and place. In connection with that, the companion should master the help/service method, namely the method of individual guidance, group guidance and community development.

4. The FDS implementation, besides targeting the attitudes, motivations, and knowledge of beneficiaries, also pays attention to and takes into account social, cultural and environmental factors in which the poor family lives.

\section{ACKNOWLEDGMENT}

All authors contributed equally to this work. All authors discussed the results and implications and commented on the manuscript at all stages. We thank to Center for Social Welfare Research and Development. This work is supported and funded by Center for Social Welfare Research and Development Ministry of Social Affairs at 2019.

\section{REFERENCES}

[1] H. Son, H, “Conditional Cash Transfer Programs: An Effective Tool for Poverty Alleviation?, Philipina: Asian Development Bank," 2008.

[2] E. Leroy, J, L, Ruel, M and Verhofstadt, "The Impact of Conditional Cash Transfer Programmes on Child Nutrition: A Review of Evidence Using A Programme Theory framework," J. Dev. Eff., vol. 1, no. 2, 2009, doi: 10.1080/19439340902924043.

[3] M. Baba-Ar, F., Eboreime,E.A,. and Hossain, "Conditional Cash Transfers for Maternal Health Interventions: Factors Influencing Uptake in NorthCentral Nigeria," Int. J. Heal. Policy Manag., vol. 7, no. $10,2016$.
[4] K. Evans, D, K., Holtemeyer, B, and Kosec, "Evaluating the Effectiveness of a CommunityManaged Conditional Cash Transfer Program in Tanzania, Grantee," New Delhi, 2016.

[5] J. Kandpal, E, Alderman, H, Friedman, J, Filmer, D, Onishi, J, and Jorge Avalos, "A Conditional Cash Transfer Program in the Philippines Reduces Severe Stunting," J. Nutr. Community Int. Nutr., vol. 1, no. 3, 2016, doi: 10.3945/jn.116.233684.

[6] U. Oduenyi, C, Ordu, V, and Okoli, "Assessing the Operational Effectiveness of a Maternal and Child Health (MCH) Conditional Cash Transfer Pilot Programme in Nigeria," BMC Pregnancy Childbirth, 2019, doi: doi.org/10.1186/s12884-0192418-0.

[7] L. B. Rawlings, "Evaluating the Impact of Conditional Cash Transfer Programs," World Bank Res. Obs., vol. 20, no. 1, pp. 29-55, 2005, doi: 10.1093/wbro/lki001.

[8] B. Baird, S., McIntosh, C., and Ozler, "Designing Cost-Effective Cash Transfer Programs to Boost Schooling in Sub-Saharan Africa.".

[9] A. and H. de Brauw, "Must conditional cash transfer programs be conditioned to be effective? The impact of Conditioning Transfers on School Enrollment in Mexico," J. Dev. Econ., vol. 96, 2011.

[10] J. Garcia, S, and Saavedra, "Educational Impacts And Cost-Effectiveness Of Conditional Cash Transfer Programs In Developing Countries: A Meta-Analysis," 2017.

[11] M. Delgado, O, A, S., Kadelbach, V, and Mata, L, "Effects of Conditional Cash Transfers (CCT) in Anti-Poverty Programs. An Empirical Approach with Panel Data for the Mexican Case of PROSPERA-Oportunidades (2002-2012), Economies, vol. 29, 2018, doi: 10.3390/economies6020029.

[12] W. McGuire, J, "Conditional Cash Transfers in Bolivia: Origins, Impact, and Universality," in Annual Meeting of the International Studies Association, 2013.

[13] I. Habibullah, Noviana, Kebijakan Pendamping Program Keluarga Harapan. Jakarta: P3KS PRESS, 2013.

[14] H. and K. W. Kwon, "The Evolution of Cash Transfers in Indonesia: Policy Transfer and National Adaptation," Asia Pacific Policy Stud., vol. 2, no. 2, 2012.

[15] Bappenas, Perlindungan Sosial di Indonesia: Tantangan dan Arah ke Depan. Jakarta, 2014.

[16] Habibullah, "Perlindungan Sosial Komprehensif di Indonesia," Sosio Inf., vol. 3, no. 1, 2017.

[17] Direktorat Jenderal Perlindungan dan Jaminan Sosial, Pedoman Pelaksanaan Program Keluarga Harapan. 2014.

[18] A. Faisol, "Proses Graduasi mandiri PKH di Bangkalan Terkendala KPM," tribunnews.com, 2019. [Online]. Available: https://surabaya.tribunnews.com/2019/03/03/proses- 
graduasi-mandiri-pkh-di-bangkalan-terkendala-kpm.

[19] L. . . C, "Managing Change: The Role Of The Change Agent," Int. J. Manag. Business, Adm., vol. 13, no. 1, 2010.

[20] S. Anwar, "Agen Perubahan (Agent of Change)," Media BPPK, 2013. [Online]. Available: https://mediabppk.kemenkeu.go.id/pbold/images/file/pusbc/Artikel/2013_AGEN_PERUB AHAN.pdfS.

[21] H. Najidah, N dan Lestari, "Efektivitas Program Keluarga Harapan (PKH) Di Kelurahan Rowosari Kecamatan Tembalang Kota Semarang," Semarang, 2019.

[22] W. Jayanti, "Pengaruh Program Keluarga Harapan Terhadap Kesejahteraan Keluarga di Desa Pasar X Kecamatan Kutalimbaru Kabupaten Deli Serdang," 2018.

[23] M. Rohmi, "Efektivitas Kebijakan Penanggulangan Kemiskinan Berbasis Bantuan dan Perlindungan Sosial Bagi Masyarakat (Studi Kasus Di Kabupaten Pringsewu Provinsi Lampung)," Lampung.

[24] C. Robertson, "6 Factors That Influence Our Behavior,” 2016. [Online]. Available: http://www.willpowered.co/learn/factors-ofbehavior-influence .

[25] K. Ogden, J, Karim, L, Chodry, A and Brown, "Understanding Successful Behaviour Change: The Role of Intentions, Attitudes To The Target and Motivations and The Example of Diet," Health Educ. Res., vol. 22, no. 3, 2007.

[26] D. Lockton, "Attitudes, Meaning, Emotion and Motivation in Design for Behaviour Change," 2012.

[27] R. Palupi, T and Sawiri, D, "Relationship Between Attitude And Pro-Environmental Behavior from the Perspective of Theory of Planned Behavior," in Proceeding Biology Education Conference, 2017.

[28] F. Avelino et al., "Transformative social innovation and (dis)empowerment," Technol. Forecast. Soc. Change, vol. 145, pp. 195-206, Aug. 2019, doi: 10.1016/j.techfore.2017.05.002.

[29] A. Gifford, R, and Niisson, "Personal and Social Factors That Influence pro environmental concern and behaviour," A Rev. Int. J. Psychol., 2014, doi: 10.1002/ijop.12034. 